\title{
Determination of arsenic, cadmium, selenium, zinc and other trace elements in Bangladeshi fish and arsenic speciation study of Hilsa fish flesh and eggs: Implications for dietary intake
}

\author{
Shaban W. Al-Rmalli ${ }^{\mathrm{a}, \dagger}$, Richard O. Jenkins ${ }^{\mathrm{a}}$, Michael J. Watts ${ }^{\mathrm{b}}$ and Parvez I. Haris ${ }^{\mathrm{a}, *}$

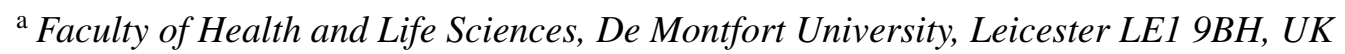 \\ ${ }^{\mathrm{b}}$ Inorganic Geochemistry, Centre for Environmental Geochemistry, British Geological Survey, \\ Keyworth, Nottingham NG12 5GG, UK
}

This article is dedicated to the memory of Dr Shaban Al-Rmalli, the first author, who carried out the experimental work and wrote most of the paper. He passed away on Friday 8th January 2021 in Tripoli, Libya.

\begin{abstract}
Exposure to As from drinking water and its impact on the health of the Bangladeshi population has received much attention. However, very little information is available regarding As exposure through consumption of fish, which is the main source of animal protein for the majority of Bangladeshis. In this study, concentrations of $\mathrm{As}, \mathrm{Cd}, \mathrm{Pb}, \mathrm{Mn} \mathrm{Se}$ and $\mathrm{Zn}$ in different types of fish, consumed by Bangladeshis, were determined using Inductively Coupled Plasma Mass Spectrometry. Daily intakes of the toxic elements $\mathrm{As}, \mathrm{Cd}$ and $\mathrm{Pb}$ through fish consumption were estimated to be 31.8, 0.4 and $4.8 \mu \mathrm{g} / \mathrm{day}$, respectively. Hilsa (Tenualosa ilisha) contained the highest concentrations of total As (mean \pm SD was $2.55 \pm 1.3 \mathrm{mg} / \mathrm{kg} ; n=15$ ) among the fish analysed. However, toxic inorganic As species were not detected. The dominant As species in Hilsa fish were: dimethylarsenic acid, arsenobetaine and arsenosugars, at 69, 11 and $20 \%$ of total As, respectively. The high concentration of Cd detected in Hilsa eggs (average $278 \pm 518 \mu \mathrm{g} / \mathrm{kg}$; range 7.4-1725 $\mu \mathrm{g} / \mathrm{kg} ; n=10$ ) is of concern since this may have harmful effects on the development of embryos and lead to a decline in the Hilsa population or the quality of the fish. It can also be harmful to those who consume Hilsa eggs on a regular basis. Selenium was found to be highest in Shoal (Micropterus cataractae) fish and a type of small fish, and lowest in Mrigal (Cirrhinus cirrhosis). Small fish species contained Mn and Zn at 7.1- and 4.3-fold higher concentrations, respectively, compared to big fish species. Keski (Corica soborna), a small fish species, contained by far the highest concentrations of $\mathrm{Mn}(52 \mathrm{mg} / \mathrm{kg})$ and $\mathrm{Zn}(140 \mathrm{mg} / \mathrm{kg})$, although the concentration of As $(1.4 \mathrm{mg} / \mathrm{kg})$ in this fish was lower than that of several other fish species. Small fish species are often consumed whole, including the bones, and therefore the essential trace elements present are potentially bioavailable for cellular metabolism. Our study shows that the Bangladeshi population can easily meet their daily requirement of Se and $\mathrm{Zn}$ from consumption of fish such as Shoal fish (Se and $\mathrm{Zn}$ ), Hilsa fish (Se and $\mathrm{Zn}$ ) and Keski fish (Se and Zn). Consumption of small fish (such as Keski) and big fish (such as Hilsa) from Bangladesh can provide valuable sources of essential trace elements as part of a balanced diet and thus negate the need for supplements and biofortifi-
\end{abstract}

\footnotetext{
$\dagger$ Author deceased.

*Corresponding author. E-mail: pharis@dmu.ac.uk.
} 
cation of certain foods. Ours is a small study and a detailed total dietary intake and human biomonitoring studies, that includes coverage of different socio-economic groups, are needed in Bangladesh before giving people supplements or biofortified foods.

Keywords: Bangladeshi diet, Hilsa, Keski, fish, eggs, arsenic, selenium, zinc, cadmium, lead, manganese, arsenic speciation, toxic and essential elements

\section{Introduction}

Arsenic (As) is a toxic element for humans that can cause a range of cancers, such as liver and lung cancers, and can also cause skin lesions (Ahsan et al. [1]; Melkonian et al. [44], Cascio et al. [13], EFSA [8]). Arsenic occurs in almost all foods, including rice and seafood, and at different concentrations. Food is usually the largest source of As exposure (WHO [71], Francesconi et al. [19], EFSA [8]). Fish and seafood generally contain large amounts of As mostly as organic forms (e.g. arsenobetaine, AsBet), which are less harmful than the inorganic species of As. It has been reported that after ingestion of AsBet around $80 \%$ is excreted unchanged from the human body (Kaise et al. [34], Lai et al. [39]) although one study suggests that it may be stored in the body (Newcombe et al. [49]). Both organic and inorganic forms of As occur in foods and fish can accumulate sizeable quantities of As from their environment (Ebisuda et al. [16]).

Cascio et al. [13] was the first to demonstrate that the Bangladeshi population in the UK is exposed to higher levels of total As and inorganic As compared to other groups through a human biomonitoring study. An earlier study by Al-Rmalli et al. [2]) analysed foods consumed by the Bangladeshi community in the UK and raised concerns that they may be exposed to higher levels of arsenic [2]. The Bangladeshi population, in Bangladesh, depends mainly upon fish as the main source of animal protein in their diet and a variety of different species of fish are consumed (Roos et al. [55], Cascio et al. [13]). Despite this, few studies in the literature have determined the As content of Bangladeshi fish (Rahman et al. [53], Das et al. [15]) and there are no reports of As speciation studies for these fish. Several studies, however, have reported on As concentrations in sea fish from other parts of the world (Baeyeans et al. [10], Vieira et al. [66], Storelli et al. [62]). Baeyeans et al. [10], for instance, determined As concentrations in different types of sea fish from the North Sea and reported total As at $12.8 \pm 12.0 \mu \mathrm{g} / \mathrm{kg}$ (wet weight); organic As species were the major forms of As in these fish, with a low proportion of inorganic As at $1.03 \%$.

Bangladeshis are a fish loving people and they proudly refer to themselves as "Mache Bhate Bangali" which can be roughly translated as "Fish and Rice Makes a Bengali" (Cascio et al. [13]). Fish is the main meat consumed by Bangladeshis and it is the major protein source consumed in Bangladesh (Zaman et al. [74]). In addition, fish provides a diverse range of nutrients for Bangladeshis (Bogard et al. [12]). Joy et al. [29] illustrated the significant influence of a fish diet on the overall dietary intake of key micronutrients in proximity to Lake Malawi in comparison to districts at distance from fishing grounds. It has been reported that fish consumption generates more health benefits, provides livelihoods for millions of people and produces climate benefits as well (Irz et al. [26], https://bluefood.earth/). However, fish can potentially be a source of high exposure to toxic elements such as $\mathrm{Cd}$ and $\mathrm{Pb}$ due to environmental pollution (Perugini et al. [51]). These elements can bioaccumulate and remain in the human body over long periods. For example, Cd has a half-life 10-30 years in humans (Jarup et al. [27]) and exerts its toxic effects mainly on the kidney (Bernard [11]). It has been reported that over 20 million people in Bangladesh suffer from kidney disease, especially chronic kidney disease (https://www.nikdu.org. 
bd/). Certain populations (in Bangladesh) are exposed to high concentrations of Cd. For example, $\mathrm{Cd}$ concentrations in the breast milk of Bangladeshi women have been shown to be the highest (median 0.14 $\mu \mathrm{g} / \mathrm{L}$ ) compared to other countries (median $<0.1 \mu \mathrm{g} / \mathrm{L}$ ) (Kippler et al. [36]). Lead can also accumulate in the human body over long periods and an association between $\mathrm{Pb}$ exposure and neurotoxicity has been reported (Verstraeten et al. [65]). On the other hand, fish can be a good source of essential elements for the human body (Perugini et al. [51]). For example, Mn, Se, Zn and I are important for human health (Joy et al. [31], Watts et al. [69], Zia et al. [75]). However, excess exposure or deficiency of these elements can affect human body functions and result in chronic diseases (Fergusson [17], Li [40] and Santamaria [57]).

For the first time, speciation of As in Hilsa (Tenualosa ilisha) fish flesh and eggs was investigated. This is the national fish of Bangladesh and 65\% of world's Hilsa is produced there (Alam and Naser [6]). It migrates from the Bay of Bengal to rivers to spawn. It is a nutritious fish, rich in proteins and essential fatty acids (Alam and Naser [6]). It is by far the most loved and sought after fish in Bangladesh. In addition to providing animal protein, livelihoods of millions of people in Bangladesh, Myanmar and West Bengal in India depend on Hilsa fish (Hossain et al. [24]). Therefore, research on this fish is of utmost importance. In the current study, total concentrations of six elements - three toxic $(\mathrm{As}, \mathrm{Cd}, \mathrm{Pb})$ and three essential (Mn, Se, Zn) - in Bangladeshi fish (big fish species flesh without bones; Hilsa fish eggs and whole small fish species including bones) were determined.

\section{Materials and methods}

\subsection{Sampling and sample preparation}

Bangladeshi fish samples (12 types, accurate description in Table 2) originating mainly from Bangladesh and Myanmar were included in the study. Frozen samples were purchased from ethnic Bangladeshi shops in the UK during 2008 and 2009. These types of fish are consumed mainly by the Bangladeshi community in the UK. Example of a big fish (Hilsa) and a small fish (Keski) are shown in Fig. 1 and Fig. 2, respectively.

For preparation of fish and eggs samples for analysis, the frozen fish were defrosted and cleaned using deionised water. The flesh of big fish species were separated from the bones and the flesh samples were dried using a freeze dryer and then analysed. However, the small fish species were analysed as whole fish (flesh and bones) since these fish are generally consumed whole including bones. The freeze-dried fish samples were ground and prepared for analysis.

For sample digestion, a dry ground weight $(0.3-0.5 \mathrm{~g})$ of fish (for eggs wet weight was used) was mixed with $4 \mathrm{ml}$ of $70 \%$ nitric acid $\left(\mathrm{HNO}_{3}\right)$ (Romil-UpA, Ultra Purity acid) and $2 \mathrm{ml}$ of hydrogen peroxide $\left(\mathrm{H}_{2} \mathrm{O}_{2}\right)$ and then digested for 40 minutes using a microwave digestion unit at a maximum temperature of $170^{\circ} \mathrm{C}$ (CEM, Microwave digestion MAR Xpress, USA). The digested solution was evaporated to dryness and then diluted to $25 \mathrm{ml}$ in volumetric flasks with ultra-pure water (Romil-UpS, Ultra Purity water) for analysis.

For As speciation, accurate weight $(0.2-0.5 \mathrm{~g})$ of the relevant sample was transferred to a Teflon tube. Subsequently, $10 \mathrm{ml}$ of deionised water was added and the extraction process was carried out through microwave heating (CEM Mars Xpress) for 30 minutes at $80^{\circ} \mathrm{C}$, and then $5 \mathrm{ml}$ of deionised water was added and the extract passed through a $0.45 \mu \mathrm{m}$ syringe filter. The As in the extract was immediately determined using HPLC-ICP-MS; the method used is described Section 2.3. 


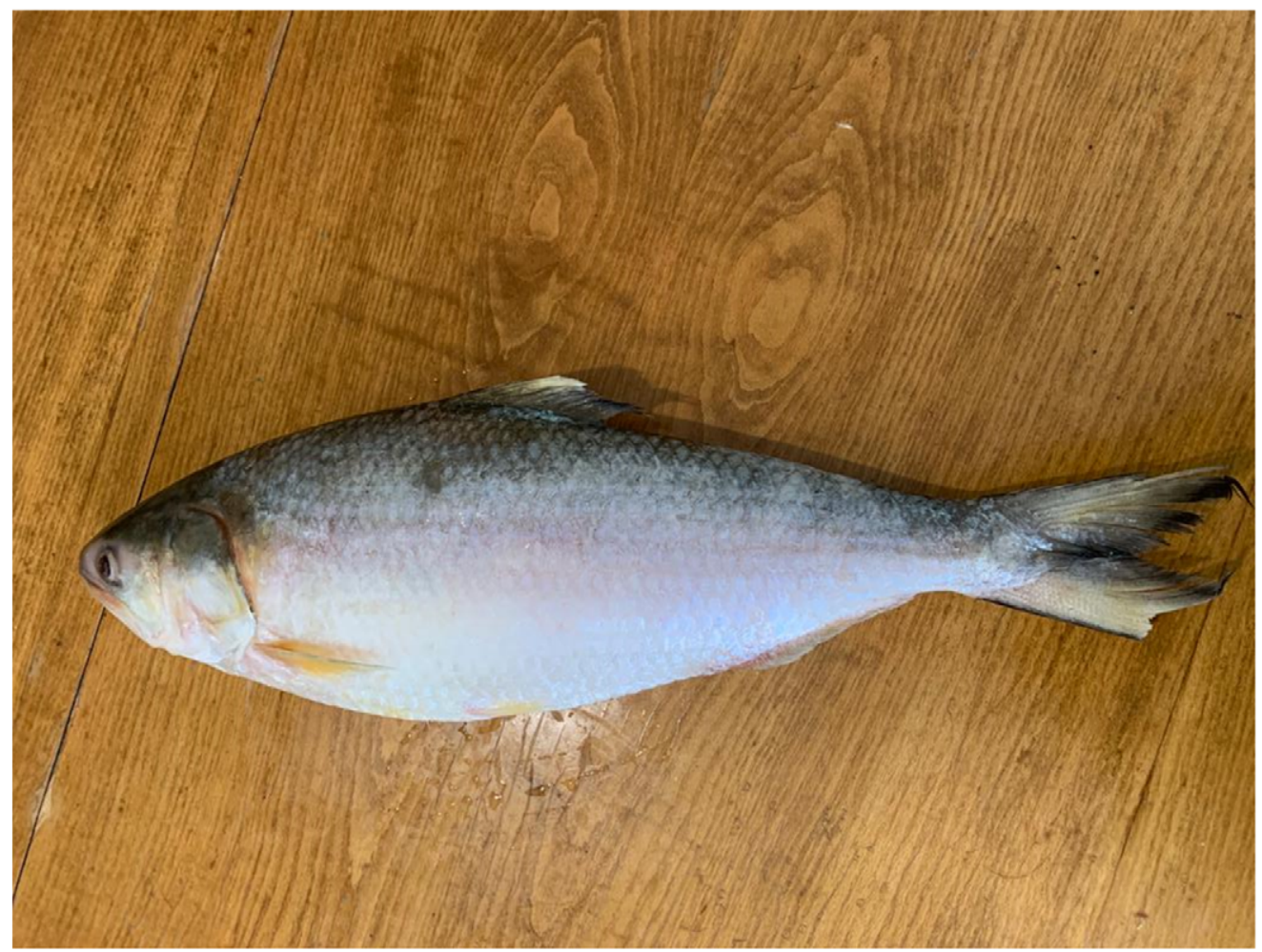

Fig. 1. Example of a big fish investigated in this study. This is Hilsa fish from Bangladesh purchased from an ethnic supermarket in the UK. The length of the Hilsa fish can vary, for example from $168 \mathrm{~mm}-590 \mathrm{~mm}$ (Salini et al. [56], Rahman and Cowx [52]).

\subsection{Trace element analysis by ICP-MS}

Total concentrations of $\mathrm{As}, \mathrm{Cd}, \mathrm{Pb}, \mathrm{Mn}, \mathrm{Se}$ and $\mathrm{Zn}$ in the digested samples were determined by ICPMS (Thermo-Fisher Scientific X-SeriesII). Details of ICP-MS conditions used are similar to those reported previously (Al-Rmalli et al. [4,5]). The analytical procedure and the reliability of the digestion process was validated by analysis of standard reference materials (Typical Japanese food (NIES) No. 27; seaweed (NIES) No. 9, Japan). Arsenic, Cd, Mn, Pb, Se and Zn concentrations obtained by ICP-MS analysis were found to be in good agreement with the certified values of the reference materials (see Table 1).

\subsection{Arsenic speciation}

HPLC-ICP-MS was used to analyse As species in selected Hilsa fish sample extracts. A PRP-X100, $10 \mu \mathrm{m}$ anion-exchange column $(150 \times 4.1 \mathrm{~mm}$; Hamilton, USA $)$ was used for the separation of the As species. Calibration standards used a mixed solution comprising of $\mathrm{As}^{\mathrm{III}}, \mathrm{As}^{\mathrm{V}}, \mathrm{DMA}^{\mathrm{V}}$ (Dimethylarsinic acid) and $\mathrm{MMA}^{\mathrm{V}}$ (monomethylarsonic acid). Detailed elemental speciation analysis was only conducted for As. For the calculation of recoveries, the total As concentration in the fish extract was determined using an Agilent 7500 ICP-MS (Agilent Technologies, UK) instrument. Details of instrumental set-up and operating conditions have been reported previously (Watts et al. [67,68], Middleton et al. [45]). Extraction efficiencies (\%) were compared with tuna fish certified reference material (BCR-627) (Table 1). 


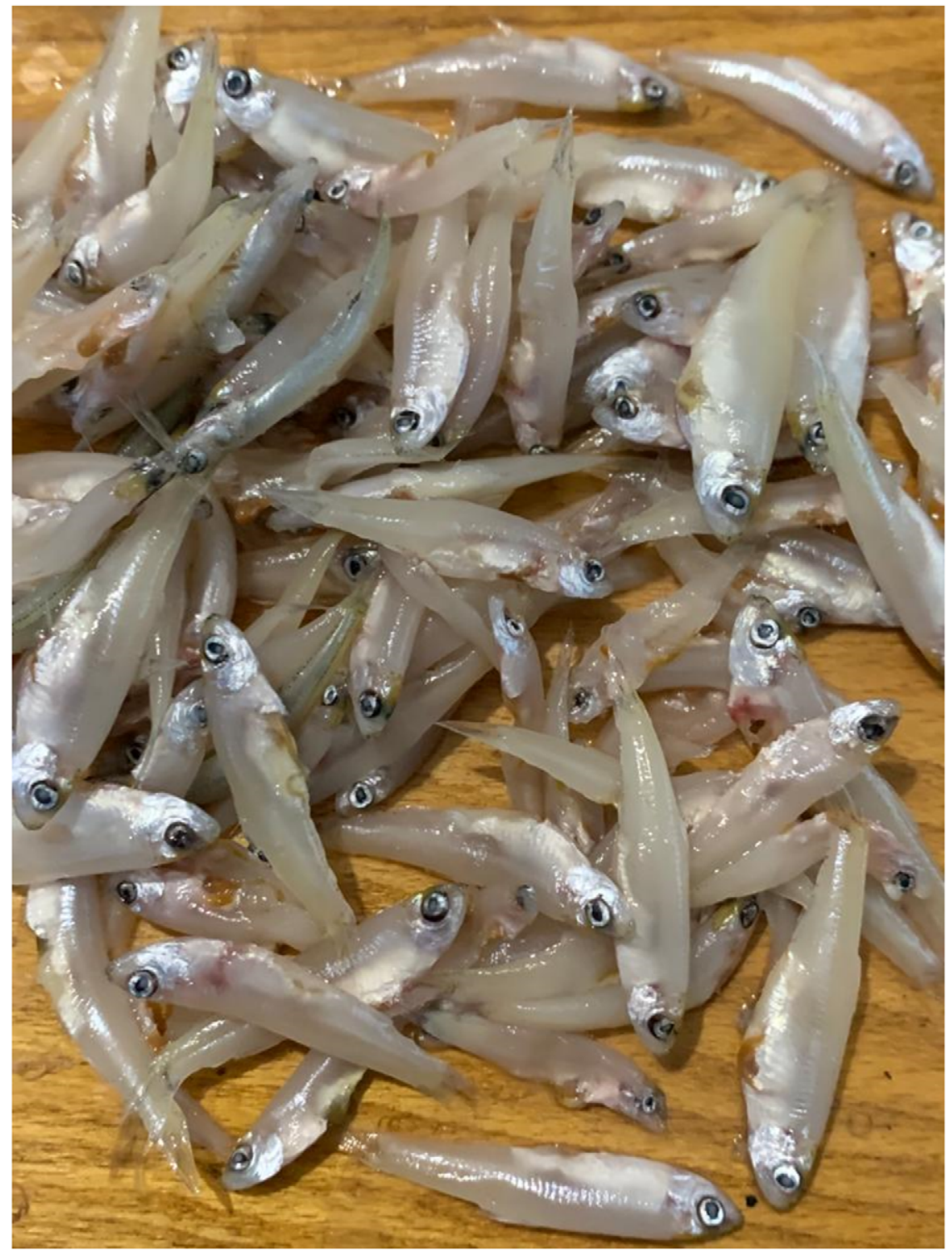

Fig. 2. Example of a small fish investigated in this study. This is Keski fish (Corica soborna) which belongs to the Clupeidae Family (Hossain et al. [25]) and is very popular in Bangladesh and amongst Bangladeshis in the UK. It is consumed whole with the bones. The size of the Keski fish is about 3-4 cm in length (Hossain et al. [25]).

\subsection{Daily intake (DI) of As, Cd, Pb, Mn, Se and $\mathrm{Zn}$}

Quantities of fish (big and small) consumed by the Bangladeshi population were taken from Zablotska et al. [73]. These quantities and the average concentration of elements found in big and small fish species from our results were used for calculating daily intakes (DI) of different elements from fish consumption 
Table 1

Trace elements and arsenic species content in standard reference materials

\begin{tabular}{|c|c|c|c|c|}
\hline \multirow[t]{2}{*}{ Element } & \multicolumn{2}{|c|}{ Seaweed (NIES No. 9) } & \multicolumn{2}{|c|}{ Typical Japanese diet (NIES No. 27) } \\
\hline & $\overline{\text { Certified value (mg/kg) }}$ & Found value $(\mathrm{mg} / \mathrm{kg})$ & $\overline{\text { Certified value (mg/kg) }}$ & Found value $(\mathrm{mg} / \mathrm{kg})$ \\
\hline As & $115 \pm 9$ & $105 \pm 12$ & $0.60 \pm 0.04$ & $0.562 \pm 0.05$ \\
\hline$C d$ & $0.150 \pm 0.02$ & $0.164 \pm 0.05$ & $0.069 \pm 0.009$ & $0.072 \pm 0.01$ \\
\hline$M n$ & $21.2 \pm 1.0$ & $23.4 \pm 1.7$ & $8.9 \pm 0.2$ & $8.7 \pm 0.6$ \\
\hline $\mathrm{Pb}$ & $1.35 \pm 0.05$ & $1.45 \pm 0.07$ & 0.62 & 0.596 \\
\hline $\mathrm{Se}$ & 0.05 & 0.06 & $0.25 \pm 0.02$ & $0.28 \pm 0.07$ \\
\hline$Z n$ & $15.6 \pm 1.2$ & $13.9 \pm 1.6$ & $20.9 \pm 0.9$ & $18.7 \pm 1.2$ \\
\hline
\end{tabular}

Arsenic species $\quad$ Concentrations of arsenic species in Tuna fish (certified reference material BCR-627)
and extraction efficiency

\begin{tabular}{lc}
\hline Total As (certified value, $\mathrm{mg} / \mathrm{kg})$ & $4.80 \pm 0.30$ \\
Extraction efficiency $(\%)$ & 99 \\
AsCol $(\mathrm{mg} / \mathrm{kg})$ & 0.0001 \\
AsBet $(\mathrm{mg} / \mathrm{kg})$ & 3.28 \\
DMA $(\mathrm{mg} / \mathrm{kg})$ & 0.168 \\
AsSugar $(\mathrm{mg} / \mathrm{kg})$ & 0.008 \\
Unknown $(\mathrm{mg} / \mathrm{kg})$ & 0.014 \\
Sum of species $(\mathrm{mg} / \mathrm{kg})$ & $3.47 \pm 0.30$ \\
Column recovery $(\%)$ & 73
\end{tabular}

(Al-Rmalli [3]).

DI of fish $=$ Concentration of element $\left(\frac{\mu g}{g}\right) *$ Quantity of consumed fish $(g)$

\section{Results}

\subsection{Total concentrations of As in fish}

In this study, 12 varieties of freshwater fish and one variety of sea fish (Hilsa), sold in ethnic Bangladeshi shops in the UK, were analysed (Table 2) for their As content. The highest As content was detected in Hilsa fish at $6.15 \mathrm{mg} / \mathrm{kg}$. Mean concentrations of As ranged from $0.005-4.94 \mathrm{mg} / \mathrm{kg}$ for flesh of big fish species and from $0.1-2.55 \mathrm{mg} / \mathrm{kg}$ for small fish species, respectively (Table 2). The mean concentrations of As in Hilsa fish eggs was found to 2.55 and $4.94 \mathrm{mg} / \mathrm{kg}$ from Bangladesh and Myanmar, respectively.

\section{2. $\mathrm{Cd}$ and $\mathrm{Pb}$ in fish}

The highest concentration of Cd was found in Hilsa eggs from Bangladesh at $1725 \mu \mathrm{g} / \mathrm{kg}$, and the highest $\mathrm{Pb}$ concentration $(1160 \mu \mathrm{g} / \mathrm{kg}$ ) was found in Rhui fish (Labeo rohita) from Bangladesh. Mean concentrations of $\mathrm{Cd}$ ranged from 0.6-22.6 $\mu \mathrm{g} / \mathrm{kg}$ for flesh of big fish species and 1.8-188 $\mu \mathrm{g} / \mathrm{kg}$ for whole small fish species. For $\mathrm{Pb}$, mean concentrations ranged from 19-250 $\mu \mathrm{g} / \mathrm{kg}$ for flesh of big fish species and 15.8-124.5 $\mu \mathrm{g} / \mathrm{kg}$ for small fish species. Cd concentrations were high in Shoal fish (Channa striata) liver at $121 \mu \mathrm{g} / \mathrm{kg}$, compared with Shoal fish flesh $(1.1 \mu \mathrm{g} / \mathrm{kg})$, whereas relatively low Cd concentrations of 0.6 and $1.5 \mu \mathrm{g} / \mathrm{kg}$ were found in Rhui fish (Labeo rohita) from Myanmar and Mrigal fish 
Table 2

As and Se (mg/kg) concentrations in different types of fish consumed by Bangladeshis in the UK and in Bangladesh

\begin{tabular}{|c|c|c|c|c|c|c|c|}
\hline \multirow[t]{2}{*}{ Sample } & \multirow[t]{2}{*}{$N$} & \multicolumn{3}{|c|}{ As } & \multicolumn{3}{|c|}{$\mathrm{Se}$} \\
\hline & & Mean \pm SD & Min & $\operatorname{Max}$ & Mean \pm SD & Min & $\overline{M a x}$ \\
\hline \multicolumn{8}{|l|}{ Big fish species $^{\&}$} \\
\hline Hilsa (Tenualosa ilisha) (BD) & 15 & $2.55 \pm 1.3$ & 0.77 & 4.44 & $0.90 \pm 1.31$ & 0.21 & 1.25 \\
\hline Hilsa (Myanmar) & 3 & $4.94 \pm 0.7$ & 4.36 & 6.15 & $0.43 \pm 0.03$ & 0.41 & 0.46 \\
\hline Rhui (Labeo rohita) (BD) & 14 & $0.03 \pm 0.03$ & 0.006 & 0.153 & $0.26 \pm 0.02$ & 0.05 & 0.35 \\
\hline Rhui (Myanmar) & 1 & 0.105 & - & - & 0.54 & - & - \\
\hline Ayre (Sperata aor) & 5 & $0.014 \pm 0.01$ & 0.004 & 0.032 & $0.14 \pm 0.13$ & 0.03 & 0.36 \\
\hline Shoal (Channa striata) & 1 & 0.012 & - & - & 1.66 & - & - \\
\hline Shoal fish (liver) & 1 & 0.016 & - & - & 3.06 & - & - \\
\hline Mrigal (Cirrhinus cirrhosus) & 1 & 0.005 & - & - & 0.08 & - & - \\
\hline Average of all big fish species* & 40 & $1.73 \pm 1.9$ & & & $0.76 \pm 0.86$ & & \\
\hline \multicolumn{8}{|l|}{ Small fish species\% } \\
\hline Puti (Puntius puntio) & 5 & $0.14 \pm 0.04$ & 0.02 & 0.18 & $0.35 \pm 0.1$ & 0.27 & 0.48 \\
\hline Silver fish (unknown type) & 2 & $2.55 \pm 0.6$ & 2.2 & 3.1 & $2.8 \pm 0.8$ & 2.3 & 3.4 \\
\hline Keski (Corica soborna) & 2 & $1.4 \pm 0.2$ & 1.2 & 1.5 & $0.8 \pm 0.07$ & 0.7 & 0.8 \\
\hline Chapila (Gudusia chapra) & 2 & $0.39 \pm 0.2$ & 0.21 & 0.49 & $0.6 \pm 0.2$ & 0.4 & 0.7 \\
\hline Taki (Channa punctata) & 2 & $0.09 \pm 0.007$ & 0.08 & 0.09 & $0.2 \pm 0.007$ & 0.19 & 0.20 \\
\hline Nodoi (Nandus nandus) & 2 & $0.15 \pm 0.04$ & 0.12 & 0.18 & $0.4 \pm 0.2$ & 0.2 & 0.5 \\
\hline Tit punti (Puntius ticto) & 2 & $0.103 \pm 0.02$ & 0.09 & 0.12 & $0.3 \pm 0.007$ & 0.29 & 0.30 \\
\hline Average of all small fish species & 16 & $0.43 \pm 0.6$ & - & - & $0.56 \pm 0.59$ & - & - \\
\hline \multicolumn{8}{|l|}{ Eggs } \\
\hline Fish egg (Hilsa) (BD) & 10 & $3.2 \pm 1.4$ & 1.3 & 4.8 & $2.04 \pm 0.98$ & 0.71 & 2.80 \\
\hline Fish egg (Hilsa) (Myanmar) & 1 & 4.8 & - & - & 1.48 & - & - \\
\hline
\end{tabular}

*average of big fish species excluding Shoal fish (liver). ${ }^{\&}$ For big fish, the bones were removed and only the flesh was analysed.

\#For small fish, the whole fish (including flesh and bones) were analysed since it is common for people to ingest bones of small fish such as Keski. BD: samples originating from Bangladesh

(Cirrhinus cirrhosus), respectively (Table 3). Cd concentrations in Hilsa fish eggs from Bangladesh were particularly high $(278 \pm 518 \mu \mathrm{g} / \mathrm{kg})$. The mean $\mathrm{Pb}$ concentrations in these Hilsa eggs were also high $(62.1 \pm 518 \mu \mathrm{g} / \mathrm{kg})$.

\subsection{Mn, Se and $\mathrm{Zn}$ in fish}

High concentrations of $\mathrm{Mn}$ in fish were detected, particularly for certain small fish species: Mn mean concentrations of $23.1,51.9$ and $7.6 \mathrm{mg} / \mathrm{kg}$ were found for a silver coloured fish (unidentified species), Keski (Corica soborna) and Nodoi (Nandus nandus) fish, respectively (Table 4). The mean concentrations of $\mathrm{Mn}$ in Hilsa eggs is rather high (3.4-3.5 mg/kg) compared to Hilsa fish flesh $(0.5-0.7 \mathrm{mg} / \mathrm{kg})$.

Selenium concentrations were highest in two types of big fish species (Hilsa and Shoal at 0.9 and $3.1 \mathrm{mg} / \mathrm{kg}$ respectively) and two types of small fish species (Silver coloured unidentified fish and Keski at 2.8 and $0.8 \mathrm{mg} / \mathrm{kg}$ respectively) (Table 2). The Se concentration in Hilsa fish eggs from Bangladesh is $2.04 \mathrm{mg} / \mathrm{kg}$.

Zinc concentrations in small fish species were generally higher than in big fish species, with especially high concentrations found in Keski and Nodoi types at $140 \pm 1.1$ and $45 \pm 9.4 \mathrm{mg} / \mathrm{kg}$, respectively (Table 4). The $\mathrm{Zn}$ concentration in Hilsa fish eggs from Bangladesh was in the range 16.1-37.1 mg/kg. 
Table 3

$\mathrm{Cd}$ and $\mathrm{Pb}$ concentrations $(\mu \mathrm{g} / \mathrm{kg})$ in different types of fish consumed by Bangladeshis in the UK and in Bangladesh

\begin{tabular}{|c|c|c|c|c|c|c|c|}
\hline \multirow[t]{2}{*}{ Sample } & \multirow[t]{2}{*}{$n$} & \multicolumn{3}{|c|}{$\mathrm{Cd}$} & \multicolumn{3}{|c|}{$\mathrm{Pb}$} \\
\hline & & $\overline{\text { Mean } \pm \text { SD }}$ & Min & $\overline{\operatorname{Max}}$ & $\overline{\text { Mean } \pm \text { SD }}$ & Min & $\overline{\operatorname{Max}}$ \\
\hline \multicolumn{8}{|l|}{ Big fish species } \\
\hline Hilsa (Tenualosa ilisha) (BD) & 15 & $22.6 \pm 31$ & 5.7 & 173 & $62 \pm 61$ & 22.4 & 240 \\
\hline Hilsa (Myanmar) & 3 & $11.2 \pm 3.2$ & 8.7 & 14.9 & $36.5 \pm 18.7$ & 15.9 & 52.2 \\
\hline Rhui (Labeo rohita) (BD) & 14 & $4.1 \pm 4.7$ & 0.3 & 13.1 & $250 \pm 328$ & 42.6 & 1160 \\
\hline Rhui (Myanmar) & 1 & 0.6 & - & - & 21.6 & - & - \\
\hline Ayre (Sperata aor) & 5 & $4.2 \pm 3.5$ & 1.5 & 10.4 & $67.6 \pm 15$ & 28.8 & 74.7 \\
\hline Shoal (Micropterus cataractae) & 1 & 1.1 & - & - & 32.8 & - & - \\
\hline Shoal fish (liver) & 1 & 121 & - & - & 88.7 & - & - \\
\hline Mrigal (Cirrhinus cirrhosus) & 1 & 1.5 & - & - & 19 & - & - \\
\hline Average of all big fish species* & 40 & $58.7 \pm 259$ & - & - & $124.7 \pm 205$ & - & - \\
\hline \multicolumn{8}{|l|}{ Small fish species } \\
\hline Puti (Puntius puntio) & 5 & $8.1 \pm 4.4$ & 4 & 13.7 & $240 \pm 211$ & 81 & 608 \\
\hline Silver fish (unknown type) & 2 & $188 \pm 54$ & 172 & 250 & $114 \pm 35$ & 95 & 145 \\
\hline Keski (Carica soborna) & 2 & $22 \pm 2.7$ & 20 & 24 & $78 \pm 14$ & 65 & 85 \\
\hline Chapila (Gudusia chapra) & 2 & $7.8 \pm 0.7$ & 7.2 & 8.2 & $32.4 \pm 5.3$ & 29 & 37 \\
\hline Taki (Channa punctata) & 2 & $1.8 \pm 0.7$ & 1.4 & 2.4 & $15.8 \pm 11.2$ & 10 & 26 \\
\hline Nodoi (Nandus nandus) & 2 & $2.3 \pm 0.3$ & 2.1 & 2.5 & $32 \pm 14.6$ & 21 & 41 \\
\hline Tit punti (Puntius ticto) & 2 & $1.9 \pm 0.4$ & 1.6 & 2.2 & $22.4 \pm 11$ & 16 & 31 \\
\hline Average of all small fish species & 16 & $16.1 \pm 42$ & - & - & $63.4 \pm 62$ & - & - \\
\hline \multicolumn{8}{|l|}{ Eggs } \\
\hline Fish egg (Hilsa) (BD) & 10 & $278 \pm 518$ & 7.4 & 1725 & $62.1 \pm 39$ & 9.4 & 138 \\
\hline Fish egg (Hilsa) (Myanmar) & 1 & 7.4 & - & - & 9.4 & - & - \\
\hline
\end{tabular}

*average of big fish species excluding Shoal fish (liver).

BD: Bangladesh.

\subsection{Speciation of As in Bangladeshi Hilsa fish}

Bangladeshi Hilsa fish, bought from ethnic shops in the UK, were analysed for As species. This species of big fish and its eggs contained the highest As concentration of all fish/egg samples analysed in this study. Hilsa fish is a very popular fish in the Bangladeshi diet. No previous studies have determined As species present in Hilsa fish, or in any other Bangladeshi fish. This study is therefore the first to determine As species in a Bangladeshi fish and its eggs. Eight samples of Hilsa fish flesh and four samples of Hilsa eggs were used for the As speciation measurement, with tuna fish being used as a certified reference material (BCR-627) (Table 1). AsBet, DMA and arsenosugars were detected in flesh and eggs of Hilsa fish (Figure). Extraction efficiencies (\%) were 59-89 for fish flesh and 36-50 for fish eggs. In contrast, for tuna fish tissue (BCR-627) the extraction efficiency was 99\% (see Table 5). The low extraction efficiency for Hilsa fish, especially Hilsa eggs could be due to its higher lipid content and/or the methodology employed. This needs to be investigated in the future.

Speciation data for As in Hilsa fish (flesh and eggs) samples are presented in Table 5. Arsenocholine (AsCol) was not detected in any of the fish flesh or fish eggs samples analysed, even though it was found in the tuna fish tissue reference sample. The concentrations of DMA were higher than those of AsBet in the majority of the fish flesh samples analysed; mean DMA concentration was 6-fold higher than that for AsBet. The mean concentration of arsenosugars in these samples was also higher (almost 2-fold) than 
Table 4

Mn and $\mathrm{Zn}$ concentrations ( $\mathrm{mg} / \mathrm{kg}$ ) in different types of fish consumed by Bangladeshis

\begin{tabular}{|c|c|c|c|c|c|c|c|}
\hline \multirow{2}{*}{ Sample } & \multirow[t]{2}{*}{$n$} & \multicolumn{3}{|c|}{$\mathrm{Mn}$} & \multicolumn{3}{|c|}{$\mathrm{Zn}$} \\
\hline & & Mean \pm SD & Min & $\overline{\operatorname{Max}}$ & $\overline{\text { Mean } \pm \text { SD }}$ & Min & $\overline{\operatorname{Max}}$ \\
\hline \multicolumn{8}{|l|}{ Big fish species } \\
\hline Hilsa (Tenualosa ilisha) (BD) & 15 & $0.7 \pm 0.5$ & 0.1 & 1.2 & $13.4 \pm 11.3$ & 2.7 & 22.5 \\
\hline Hilsa (Myanmar) & 3 & $0.5 \pm 0.2$ & 0.2 & 0.6 & $4.3 \pm 1.2$ & 3.5 & 5.7 \\
\hline Rhui (Labeo rohita) (BD) & 14 & $2.9 \pm 3.9$ & 0.4 & 1.1 & $6.9 \pm 5.7$ & 1.8 & 6.3 \\
\hline Rhui (Myanmar) & 1 & 0.5 & - & - & 11 & - & - \\
\hline Ayre (Sperata aor) & 5 & $1.7 \pm 1.4$ & 0.4 & 3.2 & $3.3 \pm 0.2$ & 3.0 & 3.4 \\
\hline Shoal (Micropterus cataractae) & 1 & 0.13 & - & - & 4.2 & - & - \\
\hline Shoal fish (liver) & 1 & 1.5 & - & - & 25.5 & - & - \\
\hline Mrigal (Cirrhinus cirrhosus) & 1 & 0.34 & - & - & 2.9 & - & - \\
\hline Average of all big fish species* & 40 & $1.92 \pm 2.6$ & - & - & $9.07 \pm 9.3$ & - & - \\
\hline \multicolumn{8}{|l|}{ Small fish species } \\
\hline Puti (Puntius puntio) & 5 & $4.16 \pm 2.52$ & 3.8 & 7.4 & $16.4 \pm 8.3$ & 7.3 & 27.7 \\
\hline Silver fish (unknown type) & 2 & $23.15 \pm 6.31$ & 21.5 & 30.5 & $25 \pm 3.7$ & 21 & 26 \\
\hline Keski (Carica soborna) & 2 & $51.91 \pm 0.43$ & 51.4 & 52 & $140 \pm 1.1$ & 140 & 141 \\
\hline Chapila (Gudusia chapra) & 2 & $5.69 \pm 2.72$ & 4.8 & 8.6 & $26.9 \pm 16.4$ & 21 & 44 \\
\hline Taki (Channa punctata) & 2 & $0.89 \pm 0.48$ & 0.81 & 1.5 & $6.4 \pm 1.3$ & 6.1 & 7.9 \\
\hline Nodoi (Nandus nandus) & 2 & $7.63 \pm 0.89$ & 6.9 & 8.2 & $45 \pm 9.4$ & 41 & 54 \\
\hline Tit punti (Puntius ticto) & 2 & $1.72 \pm 1.26$ & 1.5 & 3.3 & $16.2 \pm 0.3$ & 16 & 16.4 \\
\hline Average of all small fish species & 16 & $10.1 \pm 15.6$ & - & - & $37.9 \pm 39.2$ & - & - \\
\hline \multicolumn{8}{|l|}{ Eggs } \\
\hline Fish egg (Hilsa) (BD) & 10 & $3.5 \pm 1.7$ & 2.0 & 5.6 & $26.5 \pm 20$ & 16.1 & 37.1 \\
\hline Fish egg (Hilsa) (Myanmar) & 1 & 3.4 & - & - & 10.6 & - & - \\
\hline
\end{tabular}

*average for big fish species excluding Shoal fish (liver).

BD: Bangladesh.

that of AsBet, but was lower (around 4-fold) than the mean concentration of DMA. Similar proportions of these organoarsenic species were found in Hilsa fish eggs, but with a greater proportion represented by AsBet and a lesser proportion represented by arsenosugars. Figure 2 illustrates the proportional distribution of the three types of organoarsenic compounds in both Hilsa fish flesh and Hilsa eggs.

\section{Discussion}

Very little information is available in the literature about potentially harmful elements content of Bangladeshi fish, especially arsenic. Bangladeshis consume large quantities of fish and they may be exposed to high concentrations of toxic elements from fish consumption. In this paper, concentrations of some toxic elements $(\mathrm{As}, \mathrm{Cd}, \mathrm{Pb}$ ) and essential trace elements ( $\mathrm{Mn}, \mathrm{Se}$ and $\mathrm{Zn}$ ) in 12 types of Bangladeshi fish were determined. The analysis showed that the only sea fish investigated, namely Hilsa, had higher concentrations of As and Cd (4-fold) compared to the freshwater fish included in the study. However, the freshwater big fish species - Rhui and Ayer - which are consumed in Bangladesh and very popular in the Bangladeshi community in the UK contained high concentration of $\mathrm{Pb}$ and $\mathrm{Mn}$. The source of these elements in the fish cannot be easily explained since we do not have any information regarding the environment and the conditions under which they were cultivated. It is possible that $\mathrm{Pb}$ enters the fish through fish feed and/or industrial effluents. This needs to be investigated in the future. 
Table 5

Concentrations $(\mathrm{mg} / \mathrm{kg})$ of organoarsenic species in Bangladeshi Hilsa fish

\begin{tabular}{|c|c|c|c|c|c|c|c|c|c|}
\hline Sample (S) & Total As & $\begin{array}{c}\text { Extraction } \\
\text { efficiency } \\
(\%)\end{array}$ & $\mathrm{AsCol}^{2}$ & $\mathrm{AsBet}^{3}$ & DMA & Arsenosugars & Unknown & $\begin{array}{c}\text { Sum of As } \\
\text { species }\end{array}$ & $\begin{array}{c}\text { Column } \\
\text { recovery } \\
\%\end{array}$ \\
\hline \multicolumn{10}{|l|}{ Hilsa fish flesh $^{1}$} \\
\hline S1 & $2.65 \pm 0.97$ & 85 & nd & 0.217 & 0.883 & 0.270 & nd & 1.38 & 62 \\
\hline S2 & $3.12 \pm 0.87$ & 89 & nd & 0.317 & 1.096 & 0.393 & nd & 1.81 & 65 \\
\hline S3 & $3.42 \pm 1.39$ & 59 & nd & 0.025 & 1.087 & 0.283 & nd & 1.39 & 69 \\
\hline S4 & $4.01 \pm 0.5$ & 60 & nd & 0.035 & 1.248 & 0.357 & nd & 1.64 & 69 \\
\hline S5 & $3.32 \pm 1.11$ & 67 & nd & 0.041 & 1.121 & 0.288 & nd & 1.45 & 65 \\
\hline S6 & $2.45 \pm 0.65$ & 66 & nd & 0.086 & 0.704 & 0.170 & nd & 0.95 & 59 \\
\hline S7 & $1.36 \pm 0.54$ & 76 & nd & 0.167 & 0.427 & 0.075 & nd & 0.66 & 66 \\
\hline S8 & $2.27 \pm 0.43$ & 74 & nd & 0.285 & 0.671 & 0.195 & nd & 1.15 & 69 \\
\hline \multicolumn{10}{|l|}{ Hilsa fish eggs } \\
\hline S1 & $3.52 \pm 0.86$ & 50 & nd & 0.201 & 0.652 & 0.142 & nd & 0.99 & 57 \\
\hline $\mathrm{S} 2$ & $2.98 \pm 0.73$ & 36 & nd & 0.057 & 0.293 & 0.046 & nd & 0.39 & 36 \\
\hline S3 & $2.83 \pm 0.34$ & 39 & nd & 0.075 & 0.153 & 0.006 & nd & 0.23 & 21 \\
\hline S4 & $3.45 \pm 0.56$ & 40 & nd & 0.095 & 0.069 & 0.006 & nd & 0.17 & 12 \\
\hline Tuna fish (BCR-627; $n=3$ ) & $4.80 \pm 0.30$ & 99 & 0.0001 & 3.277 & 0.168 & 0.008 & 0.014 & 3.47 & 73 \\
\hline
\end{tabular}

${ }^{1}$ Hilsa fish flesh: the meat of fish without bones, ${ }^{2} \mathrm{AsCol}$, arsenocholine, ${ }^{3} \mathrm{AsBet}$, arsenobetaine.

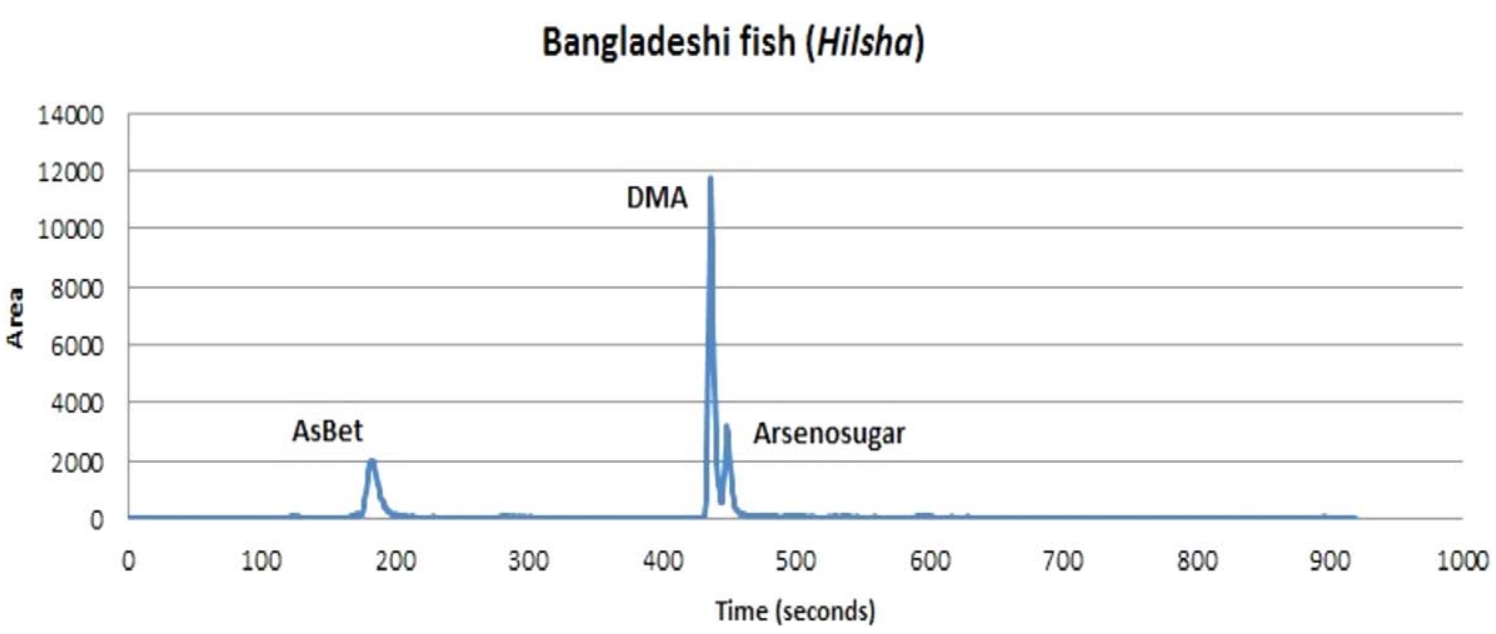

Fig. 3. Chromatogram of organoarsenic speciation in Hilsa fish flesh using HPLC-ICP-MS

\subsection{As, $\mathrm{Cd}$ and $\mathrm{Pb}$ in fish}

The highest concentration of As $(6,146 \mu \mathrm{g} / \mathrm{kg})$ was found in Hilsa fish from Myanmar (Table 2), while that for $\mathrm{Cd}(1,725 \mu \mathrm{g} / \mathrm{kg}$ ) was in Hilsa fish eggs (from Bangladesh), (Table 2). The mean content of total arsenic for Hilsa fish $(2,550-4,940 \mu \mathrm{g} / \mathrm{kg})$ found in our study is comparable to that seen for Herring by others (Julshamna et al. [32]). The similarity in total arsenic content between these two types of fish may be due to the fact that Herring and Hilsa belong to the Clupeidae family (Ghobeishavi et al. [21]). It is interesting to note that previously reported content of AsBet in Herring fish is 11\% (Lischka et al. [42]) 


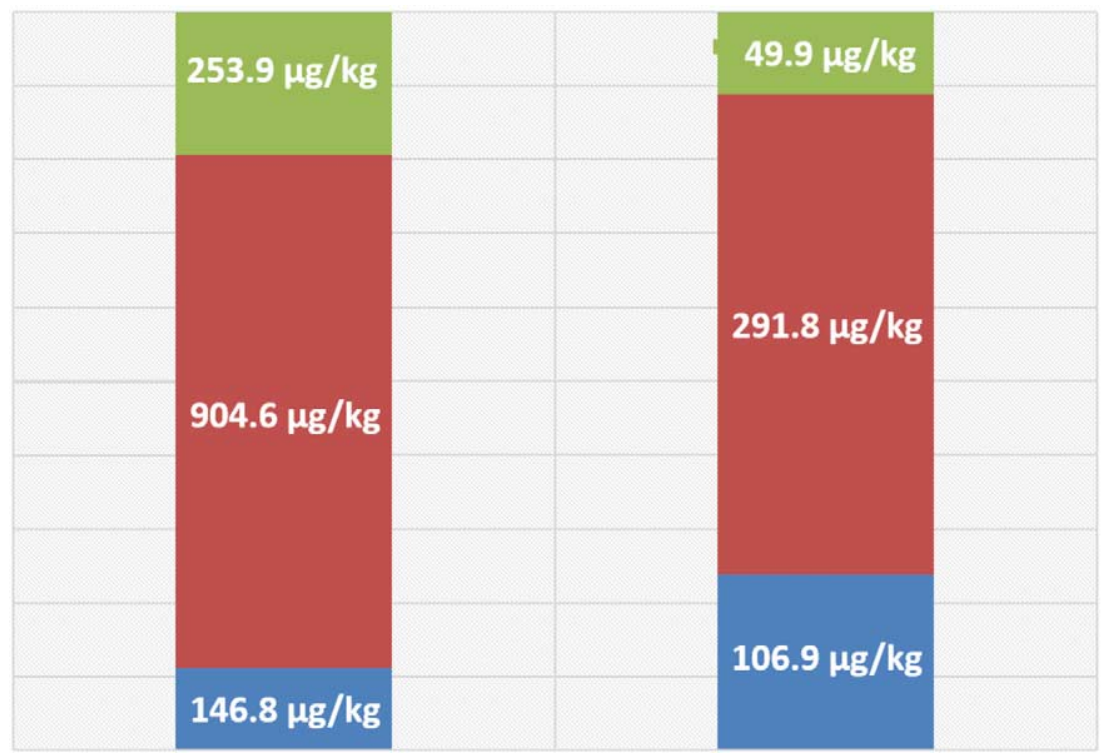

Fig. 4. Relative proportions of organoarsenic species in Hilsa fish flesh (left) and eggs (right). Mean concentrations of different As species from eight samples of fish and four samples of fish eggs. DMA (red); AsBet (blue) and arsenosugar (green).

is similar to our findings for Hilsa (11\%) (see Fig. 4). In contrast, the AsBet for other fish (salmon, hake, pilchard, mackerel, wolfish, place) ranged between $47-87 \%$ of the polar extractable arsenic (Lischka et al. [42]). The similarity in AsB content between Hilsa and Herring may not be surprising since they belong to the Clupeidae family (Ghobeishavi et al. [21]) and recent research have suggested similarities between the genomes of the two species (Das et al. [14]).

A freshwater big fish species, Rhui, was found to contain the highest concentration of $\mathrm{Pb}$ at 1,160 $\mu \mathrm{g} / \mathrm{kg}$ ) (see Table 2). Ysart et al. [72] reported on concentrations of $\mathrm{As}, \mathrm{Cd}$ and $\mathrm{Pb}$ in fish samples collected from UK markets in 1999. The concentrations of these elements were found to be 4,300 (As), $20(\mathrm{Cd})$ and $20(\mathrm{~Pb}) \mu \mathrm{g} / \mathrm{kg}$ (Ysart et al. [72]). Compared with the data for Bangladeshi fish reported in the present study, the As content is similar for some types of fish, such as Hilsa. This fish is very popular amongst Bengalis and is the national fish of Bangladesh and the state fish of West Bengal in India. It is a type of sea fish that migrates from the sea to the river for spawning (Al-Rmalli et al. [5]). The As concentrations reported by Ysart et al. [72] for UK freshwater fish are higher than those presented in the current study for Bangladeshi freshwater fish. This suggests that freshwater fish are not affected by the As pollution in Bangladesh. The small quantities of As detected in freshwater fish is likely to be present as non-toxic AsBet (Ebisuda et al. [16]). Results presented in the current study show that the seawater fish, Hilsa, contains high concentrations of As whereas inorganic As was not detected (see below).

In the present study, daily intakes of $\mathrm{As}, \mathrm{Cd}$ and $\mathrm{Pb}$ from fish consumption were estimated to be 31.76 , 0.37 and $4.76 \mu \mathrm{g} / \mathrm{day}$, respectively. The main source of $\mathrm{Cd}$ exposure in the Bangladeshi population is from rice and vegetables, with very little contribution from fish (AlRmalli [3]). This is consistent with the observation by Krajcovicova-Kudlackova et al. [38] who reported that the human blood $\mathrm{Cd}$ concentration decreases with increasing animal food consumption. The lower $\mathrm{Cd}$ intake from animal products compared to vegetables explains this observation.

It has been reported that Hilsa eggs have higher lipid content, especially $\omega-3$ PUFAs, and are richer in essential nutrients compared to Hilsa flesh (Pal et al. [50], Hossain et al. [23], Moniruzaman et al. [47]) 
Consumption of Hilsa eggs is popular amongst Bangladeshis, including those living in the UK, although its availability in Bangladeshi grocery shops in the UK has declined in recent years due to the ban on Hilsa fishing during the spawning period introduced in 2019. Hilsa eggs are more expensive compared to Hilsa fish and it is not readily available (Hossain et al. [22]).

Extremely high values of $\mathrm{Cd}$ were detected in Hilsa fish, especially Hilsa eggs. Although no previous studies have investigated heavy metal exposure in Hilsa eggs, our findings suggest that the egg shell is likely to be permeable to heavy metals such as $\mathrm{Cd}$. The cause for the high concentrations of $\mathrm{Cd}$ in fish eggs needs to be investigated in the future as it could have damaging effect on the embryos that could result in a decline in Hilsa population. It has been reported that heavy metals can penetrate eggs and cause developmental disturbances including malformations, reduced viability, reduction in body size and even death of the embryo (Jezierska et al. [28]).

Exposure to toxic elements will have a negative effect on fish quality and quantity and thereby adversely affect the nutrition of the population and the economy of the country. To protect Hilsa fish stock from depleting, the Bangladesh government has banned Hilsa fishing during peak breeding season when the marine fish swims from the Bay of Bengal to spawn in rivers (https://www. dhakatribune.com/bangladesh/2021/09/22/22-day-ban-on-ilish-fishing-starts-october-4). Hilsa fish accounts for about $12 \%$ of the country's total fish production. Bangladesh is the highest producer of Hilsa fish in the world and it has also obtained Geographical Indication Registration Certificate for this fish (https://fisheries.portal.gov.bd/sites/default/files/files/fisheries.portal.gov.bd/page/4cfbb3cc c0c4_4f25_be21_b91f84bdc45c/Fisheries\%20Statistical\%20Yearboook\%202017-18.pdf).

It is possible that $\mathrm{Cd}$ containing pollutants are entering the Bangladesh rivers (Watts et al. [70], Kibria et al. [33]) and are accumulating in fish such as Hilsa. Pollution of rivers and lakes from textile and tannery industries as well as from agricultural activities is a serious problem in Bangladesh that needs to be urgently addressed. Bangladeshis have one of the highest daily intake of $\mathrm{Cd}$ compared to other populations investigated thus far (Al-Rmalli et al. [4]). This is of concern since chronic exposure to even low levels of Cd (Ferraro et al. [18]) can increase the risk of developing chronic kidney disease (CKD). In this context, it is important to carry out further research to determine if the alarmingly high rate of CKD in Bangladesh (Anand et al. [7]) is due to high dietary cadmium exposure.

\subsection{Mn, Se and Zn in fish}

Previously we estimated the daily intakes of $\mathrm{Zn}$, Se and $\mathrm{Mn}$ from consumption of fish in Bangladesh is 927, 35.21 and $141 \mu \mathrm{g} /$ day, respectively (Al-Rmalli et al. [4,5]). The total dietary intake (TDI) of the essential element Se was estimated to be $90.4 \mu \mathrm{g} /$ day with fish being the food category with the highest contribution, followed by rice. Therefore, daily intake of Se in Bangladesh is higher than the daily recommended intake of $55 \mu \mathrm{g}$ (Monsen [48]) and is not deficient in the Bangladeshi diet as was suggested previously (Spallholz et al. [60], Spallholz et al. [61]). These latter studies formed the basis for subsequent supplementation trials even though these studies were not total diet studies and did not analyse the wide variety of foods consumed by Bangladeshis. This may explain why their estimated daily intake was $26 \mu \mathrm{g} / \mathrm{day}$ (Spallholz et al. [61]), much lower than our estimation of $90 \mu \mathrm{g} /$ day (Al-Rmalli et al. [5]). Our estimate of selenium intake agrees with blood selenium in Bangladeshi population reported in the literature, which are similar to levels in populations that are known to be not deficient in selenium (Al-Rmalli et al. [5]). However, some Bangladeshi population groups may have deficiencies, due to for example low intake of fish, and this needs to be determined through a comprehensive survey of the wider population including human biomonitoring studies like the National Health and Nutrition Examination 
Service in the USA (https://www.cdc.gov/nchs/nhanes/index.htm). This is important to avoid giving supplements to people who may already have sufficient Se intake through their diet and risk potential harmful effects of excessive selenium exposure (Rayman [54], Lv et al. [43]). High concentrations of Se in fish were measured: means of 3,060 $\mu \mathrm{g} / \mathrm{kg}$ for Shoal fish liver and 2,800 $\mu \mathrm{g} / \mathrm{kg}$ for a small silver coloured fish. It is interesting to note that many medicinal benefits have been attributed to Shoal fish (Shafri and Abdul Mannan [59]). Bangladesh people who are ill or weak are often recommended to eat soup made from this fish (personal communication by one of the authors with people from Bangladesh). Although, more research is needed, it is possible that the high concentration of Se present in this fish may confer some of the reported health benefits of this element (Schomburg et al. [58]). Manganese and $\mathrm{Zn}$ concentrations in small fish species were generally found to be higher than in big fish species. In a study from the UK, Mn, Se and Zn were detected in fish samples collected from UK markets in 1999 (Ysart et al. [72]); concentrations of these elements were 1,100, 390 and 9,100 $\mu \mathrm{g} / \mathrm{kg}$, respectively.

Our estmation of the TDI for of $\mathrm{Zn}$ and $\mathrm{Mn}$ is $11.2 \mathrm{mg} /$ day and $18.7 \mathrm{mg} /$ day, respectively. For Mn, the total dietary intake is much higher than the adequate intake level $(1.8-2.6 \mathrm{mg} / \mathrm{day})$ (https://ods.od.nih. gov/factsheets/Manganese-HealthProfessional/) but only $0.14 \mathrm{mg}$ of the $18.7 \mathrm{mg}$ is derived from fish. Consumption of fish provides $0.92 \mathrm{mg}$ of $\mathrm{Zn}$ per day. However, if certain types of fish is consumed, than the daily intake will be higher On the basis of our findings Bangladeshi fish (such as Keski, Shoal and Hilsa) can provide adequate quantities of $\mathrm{Zn}$ without having to resort to supplements or biofortified foods.

\subsection{Arsenic species in Bangladeshi fish (Hilsa species)}

Bangladeshi fish (Hilsa species), which contained a high concentration of total As, were selected for As speciation studies. The main As species detected were DMA, AsBet and arsenosugars (Table 4 and Fig. 4). Arsenobetaine is considered to be a less toxic As species for humans (Ebisuda et al. [16]) than DMA (Vega et al. [64]), which in turn is less toxic than inorganic As. No information about the toxicity of arsenosugars is currently available. In a recent study, As concentrations were reported for the urine of Bangladeshi's residing in the UK (Cascio et al. [13]), with high concentrations of DMA species in the urine was detected for the Bangladeshis compared to white Caucasians. Bangladeshis residing in the UK consume similar types of Bangladeshi fish that are consumed in Bangladesh. Hilsa fish is available in ethnic Bangladeshi shops in the UK and is popular amongst UK Bangladeshis. Thus, it is possible that DMA species detected in urine from Bangladeshis residing in the UK (Cascio et al. [13]) or in Bangladesh (Lindberg et al. [41]) can come from Hilsa fish species and/or rice consumption. Urinary DMA concentrations in Bangladeshi populations that are drinking As contaminated groundwater are generally attributed to the methylation of inorganic As present in water. However, the findings of the current study suggest that the consumption of fish such as Hilsa species could influence the urinary As species profile by altering the percentage of DMA in urine samples from Bangladeshis. Since DMA concentrations are used to indicate the methylation capacity of individuals, it is important to take into consideration the possible influence of fish consumption in future risk assessment studies. Bangladeshis mainly consume freshwater fish, especially those living in non-coastal areas. Furthermore, Hilsa is not a commonly consumed sea fish in Bangladesh. In recent times, the price of this fish has not been affordable for most Bangladeshis. Therefore, exposure to As species such as DMA from Hilsa fish consumption is unlikely to be a significant factor for most Bangladeshi's. Recently there has been some progress in research decoding the genome of the Hilsa fish (Das et al. [14], Mollah et al. [46]). More effort is needed to improvement in the habitat of the fish including addressing water pollution in rivers and Bay 
of Bengal. In this context, Ganguly et al. [20] reported metabolite and transcriptome level differences between Hilsa fish from two different habitats (river Hooghly and river Padma) suggesting a role for the environment on nutritional composition of the fish. In the future, it would be interesting to correlate these differences with the pollution of the habitats and the content of heavy metals and other toxic chemicals present in Hilsa fish. Such studies will be important to protect the fish and its habitat.

An important finding of our study is that some of the major big fish species from Bangladesh such as Rhui, Ayer and Mrigal contain relatively low concentrations of As (Table 2). In the UK, these types of fish are the most popular big fish species consumed by the Bangladeshi community. The sea fish, Hilsa, contains high concentration of As (Table 2) while toxic inorganic As was not detected. This is consistent with previous studies which have reported that the concentrations of inorganic As is negligible in most seafoods (Taylor et al. [63]) and often lower than the limit of detection in sea fish (Larsen et al. [39]).

With the exception of Keski and Silver fish (unknown species), small fish species also do not contain very high concentrations of As. Therefore, it can be concluded that the likelihood of very high exposure to As from consumption of big or small fish species is low. However, larger studies and more detailed As speciation analysis is necessary before a conclusive decision can be reached.

Another important finding of our study is that small fish species can be a significant source of dietary Mn and Zn. This accords with previous studies (Kongsbak et al. [37], Kawarazuka and Be'ne [35], Joy et al. [30,31]), which have already highlighted that small fish species - which are consumed as whole (with bones) - are an important source of $\mathrm{Zn}$. Our study revealed that on average, small fish species contained 7.1 and 4.3-times more $\mathrm{Mn}$ and $\mathrm{Zn}$, respectively, compared to big fish species. Keski fish was by far the highest $\mathrm{Mn}(52 \mathrm{mg} / \mathrm{kg})$ and $\mathrm{Zn}(140 \mathrm{mg} / \mathrm{kg})$ containing fish investigated in the present study. Interestingly, this fish contained 37-fold higher concentration of $\mathrm{Mn}$ and 100-fold higher concentration of $\mathrm{Zn}$ compared to the concentration of As $(1.4 \mathrm{mg} / \mathrm{kg})$. Small fish species, especially Keski is eaten whole with bones and therefore trace elements present in the flesh and bones of this fish are likely are to be available for uptake by the body. Further studies are needed to identify the As species present in this fish and also the bioavailability of the $\mathrm{Mn}$ and $\mathrm{Zn}$ from Keski fish. The very high content of $\mathrm{Zn}$, which is reported to be low or deficient in the Bangladeshi population (Arsenault et al. [9]), makes small fish species - especially Keski fish - particularly important for inclusion in the diet of Bangladeshis. Both Keski and Chapila fish, which have high zinc concentration, are widely available in Bangladesh and are much cheaper compared to larger fish. A previous study also demonstrated high concentration of $\mathrm{Zn}$ in Keski fish (Rahman et al. [53]).

Our study is limited by the fact we only analysed a small number of Bangladeshi fish that were sold in the UK markets. A larger study is necessary to fully evaluate the content of different elements in Bangladeshi fish and its impact on human health. It is important to carry out a comprehensive total diet study and human biomonitoring study, covering different sections of the population, before recommending supplements and biofortfied foods.

\section{Conclusion}

The national fish of Bangladesh, Hilsa, contains high concentration of As but this appears to be mainly made of up of species that are not considered to be toxic. We did not detect any toxic inorganic As in Hilsa fish which is good news for the consumers of this popular fish. Furthermore, the fish contains high concentration of essential elements, Se and Zn. However, the high concentration of Cd detected in Hilsa eggs is a cause for concern since this may have harmful effects on the development of embryos and lead 
to a decline in Hilsa quantity and quality. Other varieties of freshwater big fish species and the majority of the small fish species investigated contain relatively low total As. Overall, our study suggests that dietary intake of As through consumption of Bangladeshi fish is likely to be relatively low, although more studies are needed in this area. An important finding of our study is the high content of $\mathrm{Mn}$ and $\mathrm{Zn}$ in small fish species compared to big fish species. Since $\mathrm{Zn}$ is either low or deficient in the Bangladeshi diet, we would recommend increasing the consumption of small fish species such as Keski. However, the pollution of rivers, lakes and ponds needs to be reduced to avoid human exposure to toxic elements and damage to the fish population. Our study also reveals that Bangladeshi fish contains relatively high concentration of Se and suggests that this important element can be obtained from fish and other foods without resorting to supplements or biofortification. We also recommend that a comprehensive human biomonitoring and total dietary intake studies are conducted in Bangladesh so that an accurate information on trace element status is obtained before implementing any trials with supplements and biofortified foods. For example, our study suggests that the Bangladeshi diet is not deficient in selenium and this needs to be investigated further through larger studies. Fish can serve to address malnutrition, reduce environmental damage and provide livelihoods for millions of people in Bangladesh. However, action should be taken by policy makers to ensure sustainable fishing and the protection of lakes and rivers from pollution so that a healthy population of fish is maintained.

\section{Conflict of interest}

The authors have no conflict of interest to report.

\section{References}

[1] H. Ahsan, Y. Chen, F. Parvez, M. Argos, A.I. Hussain, H. Momotaj, D. Levy, A. Van Geen, G. Howe and J. Graziano, Health Effects of Arsenic Longitudinal Study (HEALS): Description of a multidisciplinary epidemiologic investigation, Journal of Exposure Science and Environmental Epidemiology 16(2) (2006), 191-205. doi:10.1038/sj.jea.7500449.

[2] S.W. Al Rmalli, P.I. Haris, C.F. Harrington and M. Ayub, A survey of arsenic in foodstuffs on sale in the United Kingdom and imported from Bangladesh, Science of the Total Environment 337(1-3) (2005), 23-30. doi:10.1016/j.scitotenv.2004. 06.008 .

[3] S.W. Al-Rmalli, Arsenic and other trace elements in Bangladeshi food and non-food and their relationship to human health, PhD Thesis, De Montfort University, UK, 2012.

[4] S.W. Al-Rmalli, R.O. Jenkins and P.I. Haris, Dietary intake of cadmium from Bangladeshi foods, Journal of food science 77(1) (2012), T26-T33. doi:10.1111/j.1750-3841.2011.02467.x.

[5] S.W. Al-Rmalli, R.O. Jenkins and P.I. Haris, Intake of arsenic and selenium in a Bangladeshi population investigated using inductively coupled plasma mass spectrometry, Biomedical Spectroscopy and Imaging 5(4) (2016), 373-391. doi:10.3233/ BSI-160154.

[6] S.N. Alam and M.N. Naser, Role of traditional foods of Bangladesh in reaching-out of nutrition, in: InNutritional and Health Aspects of Food in South Asian Countries, Academic Press, 2020, pp. 217-235. doi:10.1016/B978-0-12-8200117.00025-3.

[7] S. Anand, M.A. Khanam, J. Saquib, N. Saquib, T. Ahmed, D.S. Alam, M.R. Cullen, M. Barry and G.M. Chertow, High prevalence of chronic kidney disease in a community survey of urban Bangladeshis: A cross-sectional study, Globalization and health 10(1) (2014), 1. doi:10.1186/1744-8603-10-1.

[8] Food Safety Authority (EFSA), D. Arcella, C. Cascio and J.Á. Gómez Ruiz, Chronic dietary exposure to inorganic arsenic, EFSA Journal 19(1) (2021), e06380.

[9] J.E. Arsenault, E.A. Yakes, M.B. Hossain, M.M. Islam, T. Ahmed, C. Hotz, B. Lewis, A.S. Rahman, K.M. Jamil and K.H. Brown, The current high prevalence of dietary zinc inadequacy among children and women in rural Bangladesh could be substantially ameliorated by zinc biofortification of rice, The Journal of nutrition 140(9) (2010), 1683-1690. doi:10.3945/jn.110.123059. 
[10] W. Baeyens, Y. Gao, S. De Galan, M. Bilau, N. Van Larebeke and M. Leermakers, Dietary exposure to total and toxic arsenic in Belgium: Importance of arsenic speciation in North Sea fish, Mol Nutr Food Res. 53(5) (2009), 558-565. doi:10. 1002/mnfr.200700533.

[11] A. Bernard, Cadmium and its adverse effects on human health, Indian Journal of Medical Research 128 (2008), 557-564.

[12] J.R. Bogard, S.H. Thilsted, G.C. Marks, M.A. Wahab, M.A. Hossain, J. Jakobsen and J. Stangoulis, Nutrient composition of important fish species in Bangladesh and potential contribution to recommended nutrient intakes, Journal of Food Composition and Analysis 42 (2015), 120-133. doi:10.1016/j.jfca.2015.03.002.

[13] C. Cascio, A. Raab, R.O. Jenkins, J. Feldmann, A.A. Meharg and P.I. Haris, The impact of a rice based diet on urinary arsenic, Journal of Environmental Monitoring 13 (2011), 257-265. doi:10.1039/C0EM00482K.

[14] A. Das, P. Ianakiev, A. Baten, R. Nehleen, T. Ehsan, O. Ahmed, M.R. Islam, M.N. Naser, M.S. Marma and H. Khan, Genome of Tenualosa ilisha from the river Padma, Bangladesh. BMC Research Notes. 11(1) (2018), 1-3. doi:10.1186/ s13104-017-3088-5.

[15] H.K. Das, A.K. Mitra, P.K. Sengupta, A. Hossain, F. Islam and G.H. Rabbani, Arsenic concentrations in rice, vegetables, and fish in Bangladesh: A preliminary study, Environment International 30 (2004), 383-387. doi:10.1016/j.envint.2003. 09.005 .

[16] K. Ebisuda, T. Kunito, R. Kubota and S. Tanabe, Arsenic concentrations and speciation in the tissues of ringed seals (Phoca hispida) from Pangnirtung, Canada. Applied Organometallic Chemistry 16 (2002), 451-457. doi:10.1002/aoc. 319.

[17] J.E. Fergusson, The Heavy Elements: Chemistry, Environmental Impact and Health Effects, Pergamon Press, Oxford, 1990, p. 551.

[18] P.M. Ferraro, S. Costanzi, A. Naticchia, A. Sturniolo and G. Gambaro, Low level exposure to cadmium increases the risk of chronic kidney disease: Analysis of the NHANES 1999-2006, BMC public health 10(1) (2010), 1. doi:10.1186/14712458-10-1.

[19] K.A. Francesconi and S. Edmonds, Biotransformation of arsenic in the marine environment, in: Arsenic in the Environment, Part I, Cycling and Characterization, J.O. Nriagu, ed., Wiley, New York, 1994, pp. 221-262.

[20] S. Ganguly, T. Mitra, A. Mahanty, S. Mohanty and B.P. Mohanty, A comparative metabolomics study on anadromous clupeid Tenualosa ilisha for better understanding the influence of habitat on nutritional composition, Metabolomics 16(3) (2020), 1-4.

[21] A. Ghobeishavi, S.M. Mousavi, V. Yavari, P. Kochanian and M. Zakeri, The innate immunity changes of the female anadromous hilsa shad, Tenualosa ilisha, during spawning and post spawning season, Iranian Journal of Fisheries Sciences 15(4) (2016), 1526-1539.

[22] A.A. Hossain, S. Bisshas, M.M.H. Pramanik, M.M. Hasan, M.I. Haidar, A. Bosu, M.A. Rahman and M.A. Rahman, Supply chain analysis of hilsa (Tenualosa ilisha) egg in Bangladesh, Journal of Fisheries Sciences.com 12(4) (2018), 9-12.

[23] M.A. Hossain, S.M. Almatar and A.A. Al-Hazza, Proximate, fatty acid and mineral composition of hilsa, Tenualosa ilisha (Hamilton 1822) from the Bay of Bengal and Arabian Gulf, Indian J. Fish 61(2) (2014), 58-66.

[24] M.S. Hossain, S. Sarker, S.M. Sharifuzzaman and S.R. Chowdhury, Primary productivity connects hilsa fishery in the Bay of Bengal, Scientific reports 10(1) (2020), 1-16. doi:10.1038/s41598-019-56847-4.

[25] Y. Hossain, P.M. Leunda, J. Ohtomi, Z.F. Ahmed, J. Oscoz and M. Miranda, Biological aspects of the Ganges River sprat Corica soborna (Clupeidae), the Mathabhanga River(SW Bangladesh). Cybium 32(3) (2008), 241-246.

[26] X. Irz, P. Leroy, V. Réquillart and L.G. Soler, Fish in climate-friendly and healthy diets, Marine Resource Economics 33(4) (2018), 309-330. doi:10.1086/699882.

[27] L. Jarup, M. Berglund, C.G. Elinder, G. Nordberg and M. Vahter, Health effects of cadmium exposure: A review of the literature and a risk estimate, Scandinavian Journal of Work Environment and Health 24 (1998), 1-52. doi:10.5271/sjweh. 270.

[28] B. Jezierska, K. Ługowska and M. Witeska, The effects of heavy metals on embryonic development of fish (a review), Fish Physiology and Biochemistry 35(4) (2009), 625-640.

[29] E. Joy, E.L. Ander, S.D. Young, C. Black, M.J. Watts, A.D.C. Chilimba, B. Chilima, E. Siyame, A. Kalimbira, R. Hurst, S.J. Fairweather-Tait, A. Stein, R.S. Gibson, P. White and M. Broadley, Dietary mineral micronutrient supplies in Africa, Physiologia Plantarum 151 (2014), 208-229. doi:10.1111/ppl.12144.

[30] E.J.M. Joy, M.R. Broadley, S.D. Young, C.R. Black, A.D.C. Chilimba, E.L. Ander, T.S. Barlow and M.J. Watts, A spatially refined food composition table for Malawi, Science of the Total Environment 505 (2015), 587-595. doi:10.1016/j.scitotenv. 2014.10.038.

[31] E.J.M. Joy, D.B. Kumssa, M.R. Broadley, M.J. Watts, S.D. Young, A.D.C. Chilimba and E.L. Ander, Dietary mineral supplies in Malawi: Spatial and socioeconomic assessment, BMC Nutrition 1 (2016), 42. doi:10.1186/s40795-015-0036-4.

[32] K. Julshamn, B.M. Nilsen, S. Frantzen, S. Valdersnes, A. Maage, K. Nedreaas and J.J. Sloth, Total and inorganic arsenic in fish samples from Norwegian waters, Food Additives and Contaminants: Part B 5(4) (2012), 229-235. 
[33] G. Kibria, M.M. Hossain, D. Mallick, T.C. Lau and R. Wu, Monitoring of metal pollution in waterways across Bangladesh and ecological and public health implications of pollution, Chemosphere 165 (2016), 1-9.

[34] T. Kaise, S. Watanabe and K. Itoh, The acute toxicity of arsenobetaine, Chemosphere 14 (1985), 1327-1332. doi:10.1016/ 0045-6535(85)90153-5.

[35] N. Kawarazuka and C. Be' Ne', The potential role of small fish species in improving micronutrient deficiencies in developing countries: Building evidence, Public Health Nutrition 14(11) (2011), 1927-1938. doi:10.1017/S1368980011000814.

[36] M. Kippler, B. Lonnerdal, W. Goessler, E.C. Ekstrom, S. El Arifeen and M. Vahter, Cadmium interacts with the transport of essential micronutrients in the mammary gland - a study in rural Bangladeshi women, Toxicology 257 (2009), 64-69. doi:10.1016/j.tox.2008.12.009.

[37] K. Kongsbak, S.H. Thilsted and M.A. Wahed, Effect of consumption of the nutrient-dense, freshwater small fish species Amblypharyngodon mola on biochemical indicators of vitamin A status in Bangladeshi children: A randomised, controlled study of efficacy, Br J Nutr 99 (2008), 581-597. doi:10.1017/S000711450781912X.

[38] M. Krajcovicova-Kudlackova, M. Ursinyova, V. Masanova, A. Bederova and M. Valachovicova, Cadmium blood concentrations in relation to nutrition, Central European Journal of Public Health 14 (2006), 126-129. doi:10.21101/cejph. a3385.

[39] E.H. Larsen, J. Engman, J.J. Sloth, M. Hansen and L. Jorhem, Determination of inorganic arsenic in white fish using microwave-assisted alkaline alcoholic sample dissolution and HPLC-ICP-MS, Analytical and Bioanalytical Chemistry 381(2) (2004), 339-346. doi:10.1007/s00216-004-2815-7.

[40] C. Li, Selenium deficiency and endemic heart failure in China: A case study of biogeochemistry for human health, Ambio 36 (2007), 90-93. doi:10.1579/0044-7447(2007)36[90:SDAEHF]2.0.CO;2.

[41] A.L. Lindberg, M. Rahman, L.A. Persson and M. Vahter, The risk of arsenic induced skin lesions in Bangladeshi men and women is affected by arsenic metabolism and the age at first exposure, Toxicol. Appl. Pharmacol. 230 (2008), 9-16. doi:10.1016/j.taap.2008.02.001.

[42] S. Lischka, U. Arroyo-Abad, J. Mattusch, A. Kühn and C. Piechotta, The high diversity of arsenolipids in herring fillet (Clupea harengus), Talanta. 15(110) (2013), 144-152. doi:10.1016/j.talanta.2013.02.051.

[43] Q. Lv, X. Liang, K. Nong, Z. Gong, T. Qin, X. Qin, D. Wang and Y. Zhu, Advances in research on the toxicological effects of selenium, Bulletin of Environmental Contamination and Toxicology (2021), 1-12.

[44] S. Melkonian, M. Argos, M.N. Hall, Y. Chen, F. Parvez, B. Pierce, H. Cao, B. Aschebrook-Kilfoy, A. Ahmed, T. Islam, V. Slavcovich, M. Gamble, P.I. Haris, J.H. Graziano and H. Ahsan, Urinary and dietary analysis of 18,470 Bangladeshis reveal a correlation of rice consumption with arsenic exposure and toxicity, PloS one 8(11) (2013), e80691. doi:10.1371/ journal.pone.0080691.

[45] D.R.S. Middleton, M.J. Watts, E.M. Hamilton, E.L. Ander, R.M. Close, K.S. Exley, H. Crabbe, G.S. Leonardi and D.A. Polya, Urinary arsenic profiles reveal substantial exposures to inorganic arsenic from private water supplies in Cornwall, UK, Scientific Reports 6 (2016), 25656. doi:10.1038/SREP25656.

[46] M.B. Mollah, M.G. Khan, M.S. Islam and M.S. Alam, First draft genome assembly and identification of SNPs from hilsa shad (Tenualosa ilisha) of the Bay of Bengal, F1000Research (2019), 8.

[47] S.M. Moniruzzaman, M.G. Mortuza, M. Nur-Un-Nesa, M.A. Alam and A.N. Alam, Spatial variations in the nutritional profiles of young, spent, ripe or gravid hilsa (Tenualosa ilisha) flesh and eggs, International Journal of Natural and Social Sciences 1(2) (2014), 61-70.

[48] E.R. Monsen, Dietary reference intakes for the antioxidant nutrients: Vitamin C, vitamin E, selenium, and carotenoids, Journal of the American Dietetic Association 100(6) (2000), 637-640. doi:10.1016/S0002-8223(00)00189-9.

[49] C. Newcombe, A. Raab, P.N. Williams, C. Deacon, P.I. Haris, A.A. Meharg and J. Feldmann, Accumulation or production of arsenobetaine in humans?, Journal of Environmental Monitoring 12(4) (2010), 832-837. doi:10.1039/b921588c.

[50] M. Pal, T. Mukhopadhyay and S. Ghosh, Proximate, fatty acid, and amino acid compositions of fish muscle and egg tissue of Hilsa (Tenualosa) ilisha, Journal of Aquatic Food Product Technology 20(2) (2011), 160-171. doi:10.1080/10498850. 2011.557523.

[51] M. Perugini, P. Visciano, M. Manera, A. Zaccaroni, V. Olivieri and M. Amorena, Heavy metal (As, Cd, $\mathrm{Hg}, \mathrm{Pb}, \mathrm{Cu}, \mathrm{Zn}$, $\mathrm{Se}$ ) concentrations in muscle and bone of four commercial fish caught in the central Adriatic Sea, Italy. Environmental monitoring and assessment 186(4) (2014), 2205-2213. doi:10.1007/s10661-013-3530-7.

[52] M.J. Rahman and I.G. Cowx, Population dynamics of Hilsa shad (Tenualosa ilisha, Clupeidae) in Bangladesh waters, Asian Fisheries Science 21 (2008), 85-100.

[53] M.S. Rahman, A.H. Molla, N. Saha and A. Rahman, Study on heavy metals levels and its risk assessment in some edible fishes from Bangshi River, Savar, Dhaka, Bangladesh. Food chemistry 134(4) (2012), 1847-1854.

[54] M.P. Rayman, Selenium intake, status, and health: A complex relationship, Hormones 19(1) (2020), 9-14. doi:10.1007/ s42000-019-00125-5.

[55] N. Roos, M.M. Islam and S.H. Thilsted, Small indigenous fish species in Bangladesh: Contribution to vitamin A, calcium and iron intakes, The Journal of nutrition 133(11) (2003), 4021S-4026S. 
[56] J.P. Salini, D.A. Milton, M.J. Rahman and M.G. Hussain, Allozyme and morphological variation throughout the geographic range of the tropical shad, hilsa Tenualosa ilisha, Fisheries Research 66(1) (2004), 53-69. doi:10.1016/S01657836(03)00124-3.

[57] A.B. Santamaria, Manganese exposure, essentility \& toxicity, Indian J Med Res 128 (2008), 484-500.

[58] L. Schomburg, The other view: The trace element selenium as a micronutrient in thyroid disease, diabetes, and beyond, Hormones 19(1) (2020), 15-24. doi:10.1007/s42000-019-00150-4.

[59] M. Shafri and M.J. Abdul Manan, Therapeutic potential of the haruan (Channa striatus): from food to medicinal uses, Malaysian Journal of Nutrition 18(1) (2012).

[60] J.E. Spallholz, L.M. Boylan and M.M. Rhaman, Environmental hypothesis: Is poor dietary selenium intake an underlying factor for arsenicosis and cancer in Bangladesh and West Bengal, India?, Science of the Total Environment 323(1-3) (2004), 21-32.

[61] J.E. Spallholz, L. Mallory Boylan, J. David Robertson, L. Smith, M.M. Rahman, J. Hook and R. Rigdon, Selenium and arsenic content of agricultural soils from Bangladesh and Nepal, Toxicological and Environ Chemistry 90(2) (2008), 203-210.

[62] M.M. Storelli and G.O. Marcotrigiano, Interspecific variation in total arsenic body concentrations in elasmobranch fish from the Mediterranean Sea, Mar Pollut Bull 48 (2004), 1145-1149. doi:10.1016/j.marpolbul.2004.03.005.

[63] V. Taylor, B. Goodale, A. Raab, T. Schwerdtle, K. Reimer, S. Conklin, M.R. Karagas and K.A. Francesconi, Human exposure to organic arsenic species from seafood, Science of the Total Environment $\mathbf{5 8 0}$ (2017), 266-282. doi:10.1016/j. scitotenv.2016.12.113.

[64] L. Vega, M. Styblo, R. Patterson, W. Cullen and C.D. Wang, Germolec. Differential effects of trivalent and pentavalent arsenicals on cell proliferation and cytokine secretion in normal human epidermal keratinocytes, Toxicol. Appl. Pharmacol. 172 (2001), 225-232. doi:10.1006/taap.2001.9152.

[65] S. Verstraeten, L. Aimo and P. Oteiza, Aluminiu2m and lead: Molecular mechanisms of brain toxicity, Archives of Toxicology 82 (2008), 789-802. doi:10.1007/s00204-008-0345-3.

[66] C. Vieira, S. Morais, S. Ramos, C. Delerue-Matos and O. Mb, Mercury, cadmium, lead and arsenic concentrations in three pelagic fish species from the Atlantic Ocean: Intra- and inter-specific variability and human health risks for consumption, Food Chem Toxicol. 49(4) (2011), 923-932. doi:10.1016/j.fct.2010.12.016.

[67] M.J. Watts, T.S. Barlow, M. Button, A. Gomes, B. Bhattacharya, M.A. Alam and S.R. Sarkar, Arsenic speciation in softbottom polychaetes (Annelida) and sediments from Sundarban mangrove coastal regions, Environmental Geochemistry and Health 35 (2013), 13-25. doi:10.1007/s10653-012-9471-1.

[68] M.J. Watts, M. Button, T.S. Brewer, G.R.T. Jenkin and C.F. Harrington, Quantitative arsenic speciation in two species of earthworms from a former mine site, Journal of Environmental Monitoring 10 (2008), 753-759. doi:10.1039/b800567b.

[69] M.J. Watts, E.J.M. Joy, M.R. Broadley, S.D. Young, E.L. Ander, A.D.C. Chilimba, R.S. Gibson, E.W.P. Siyame Kalimbira and B. Chilima, Iodine source apportionment in the Malawian diet, Scientific Reports 5 (2015), 1521. doi:10.1038/ srep15251.

[70] M.J. Watts, S. Mitra, A. Marriott and S.K. Sarkar, Source, distribution and ecotoxicological assessment of multielements in superficial sediments of a tropical turbid estuarine environment: a multivariate approach, Marine Pollution Bulletin 115(1-2) (2017), 130-140.

[71] WHO, 1982. Food Additives Series 18. Arsenic.

[72] G. Ysart, P. Miller, H. Crews, P. Robb, M. Baxter, C. De L'argy, S. Lofthouse, C. Sargent and N. Harrison, Dietary exposure estimates of 30 elements from the UK total diet study, Food Additives and Contaminants 16 (1999), 391-403. doi:10.1080/026520399283876.

[73] L.B. Zablotska, Y. Chen, J.H. Graziano, F. Parvez, A. Van Geen, G.R. Howe and H. Ahsan, Protective effects of B vitamins and antioxidants on the risk of arsenic-related skin lesions in Bangladesh, Environ Health Perspect. 116 (2008), 1056-1062. doi:10.1289/ehp.10707.

[74] M. Zaman, M.N. Naser, A.T.M. Abdullah and N. Khan, Nutrient contents of some popular freshwater and marine fish species of Bangladesh, Bangladesh Journal of Zoology 42(2) (2015), 251-259. doi:10.3329/bjz.v42i2.23367.

[75] M. Zia, M.J. Watts et al., Health risk assessment of PHE and DM in sewage applied agricultural soils, Environmental Geochemistry and Health, 2016. doi:10.1007/s10653-016-9841-1. 